\title{
DEGRADATION OF SYNTHETIC ORGANIC DYES IN SOLUTION BY FERRATE - HYPOCHLORITE OR CALCIUM HYPOCHLORITE
}

\section{Pablo Marcelo Pérez García, Sandra L. Ibáñez-Calero and Ramiro Escalera Vásquez}

\begin{abstract}
This study investigated the use of ferrate - hypochlorite solution or solid $\mathrm{Ca}(\mathrm{OCl})_{2}$ as treatment options to remove color and COD from solutions of the synthetic organic dyes: Reactive blue 19, Allura red and Reactive black 5. It was found that doses around $1000 \mathrm{ppm} \mathrm{Ca}(\mathrm{OCl})_{2}$ had color removal efficiencies around $90 \%$ for all the dyes after 15 minutes reaction time; this treatment had a COD removal efficiency of $97 \%$ for azo dye Allura red. The ferrate hypochlorite $(0.06 \mathrm{mM}-<400 \mathrm{ppm})$ treatment resulted in a 50\% color removal for Reactive blue 19 dye after 1 hour reaction time. The COD removal of Reactive blue 19 dye was improved from $40 \%$ to $84 \%$ when the ferrate hypochlorite solution was used.
\end{abstract}

Keywords: Ferrate, Synthetic Organic Dyes, Hipochlorite, COD Removal.

DOI: 10.23881/idupbo.017.1-4i 